Article

\title{
Effect of Combustion Boundary Conditions and n-Butanol on Surrogate Diesel Fuel HCCI Combustion and Emission Based on Two-Stroke Diesel Engine
}

\author{
Shiye Wang ${ }^{1}$, Jundong Zhang ${ }^{1, *}$ and Li Yao ${ }^{2, *}$ \\ 1 Marine Engineering College, Dalian Maritime University, Dalian 116026, China; wangshiye@dlmu.edu.cn \\ 2 Merchant Marine College, Shanghai Maritime University, Shanghai 201306, China \\ * Correspondence: zhjundong@dlmu.edu.cn (J.Z.); yaoli@dicp.ac.cn (L.Y.)
}

check for

updates

Citation: Wang, S.; Zhang, J.; Yao, L. Effect of Combustion Boundary

Conditions and n-Butanol on Surrogate Diesel Fuel HCCI Combustion and Emission Based on Two-Stroke Diesel Engine. Atmosphere 2022, 13, 303. https://doi.org/10.3390/ atmos13020303

Academic Editors: Duanyang Liu, Kai Qin and Honglei Wang

Received: 11 January 2022 Accepted: 8 February 2022

Published: 10 February 2022

Publisher's Note: MDPI stays neutral with regard to jurisdictional claims in published maps and institutional affiliations.

Copyright: (c) 2022 by the authors. Licensee MDPI, Basel, Switzerland. This article is an open access article distributed under the terms and conditions of the Creative Commons Attribution (CC BY) license (https:/ / creativecommons.org/licenses/by/ $4.0 /)$.

\begin{abstract}
The combustion and emission characteristics of surrogate diesel fuel homogeneous charge compression ignition (HCCI) with different combustion boundary conditions and n-butanol (NB) mixing ratios are studied in this work. Engine data of a two-stroke low-speed direct-injection marine diesel engine were selected for the reactor. HCCI combustion was achieved by compressing a completely homogeneous mixture of fuel and air. The results show that NO emissions decrease slightly with the increase of initial boundary pressure at a constant equivalence ratio and initial temperature. In addition, the different initial boundary temperature has little effect on NO emission. The results also indicate that the ignition delay time of the mixed fuel rises with the increase of $\mathrm{n}$-butanol mixing ratio. The emissions and reaction rate of $\mathrm{NO}_{\mathrm{x}}$ reduce significantly with the increase of $n$-butanol percentage in surrogate diesel fuel and n-butanol mixing combustion at a constant equivalence ratio and total mole fraction. Meanwhile, $\mathrm{CO}_{2}$ emissions also decrease significantly with the increase of n-butanol mixing ratio.
\end{abstract}

Keywords: homogeneous charge compression ignition; surrogate diesel fuel; ignition delay; n-butanol; $\mathrm{NO}_{\mathrm{x}}$ emission

\section{Introduction}

The development of society and the economy is inseparable from energy. The demand for energy is increasing constantly in the current society, and the rapid consumption of fossil fuels has caused people to face a serious energy crisis. Therefore, people develop and explore new renewable and efficient fossil fuel alternative energy sources to deal with the increasingly severe energy problem [1-3]. At the same time, the massive burning of fossil fuels has also brought serious pollution problems. Large amounts of $\mathrm{CO}_{2}$ and thermal $\mathrm{NO}_{x}$ are produced when the engine burns fossil fuels. $\mathrm{NO}$ and $\mathrm{NO}_{2}$ are the two most important harmful pollutants in thermal $\mathrm{NO}_{\mathrm{x}}$ produced by combustion [4-6]. In order to alleviate the serious environmental damage caused by fossil fuels combustion, various countries have formulated different measures to control the exhaust emissions of diesel engines strictly. The European Parliament plans to limit greenhouse gas emissions to deal with the serious problem of global warming and strive to achieve the goal of reducing more than $80 \%$ in 2050 [7]. The British Parliament passed an amendment in 2019 to achieve a net zero emission target by 2050. The French National Assembly had already incorporated a net zero target into law in June 2019. Therefore, the development and utilization of new renewable clean energy is receiving more and more attention.

$\mathrm{N}$-heptane is often selected as a surrogate diesel fuel in previous simulations of diesel engines [8-10]. However, the carbon chain of actual diesel fuel is longer than that of $\mathrm{n}$-heptane fuel, and the number of carbon atoms is about 10 to 25 [11]. The composition of diesel is complicated, and it is difficult to reproduce the combustion chemistry characteristics of diesel under low-temperature combustion through a single component 
represented by $\mathrm{n}$-heptane. $\mathrm{N}$-dodecane is considered to be a closer alternative fuel to diesel than n-heptane. Earlier, Luo et al. developed a simplified one-component diesel substitute (pure $n$-dodecane) to simulate diesel engines [12]. However, the mechanism of n-dodecane lacks alkylbenzene, which is an important component in diesel. It cannot reflect the real combustion of diesel well. Then, Pei et al. developed a diesel substitution mechanism (consisting of $77 \%$ n-dodecane and $23 \%$ m-xylene) on this basis and compared it with the experimental data of shock tube. Research has found that the mixture of $m$-xylene and $\mathrm{n}$-dodecane can represent the combustion and emission characteristics of diesel fuel better than pure n-dodecane [13].

Oxygenated fuel can reduce PM and soot emissions significantly in diesel engine combustion [14-19]. At the same time, some oxygenated fuels are renewable. Oxygenated fuel can be used as a single fuel or mixed with diesel in a certain proportion. Therefore, oxyfuel is an ideal substitute for fossil energy. As a representative of the new generation of oxygenated fuel, the development and application of $n$-butanol $\left(\mathrm{C}_{4} \mathrm{H}_{10} \mathrm{O}\right)$ have attracted the extensive attention of scholars [20,21]. N-butanol has less corrosiveness and high safety. As an oxygenated fuel, burning n-butanol can reduce soot emissions effectively. The viscosity of n-butanol is lower than that of diesel, and it has better mutual solubility with diesel. The mixed combustion of $n$-butanol and diesel can be realized on the diesel engine with small changes to the engine [22-25]. In terms of environmental protection, n-butanol can be produced by biological methods, which can solve the problem of large fossil fuel consumption effectively. The renewability of n-butanol has high research value and wide application prospects.

As a new type of combustion concept, $\mathrm{HCCI}$ combustion has low $\mathrm{NO}_{\mathrm{x}}$ emissions and high combustion heat efficiency compared to traditional gasoline and diesel engines [26-28]. Analyzing the fuel combustion reaction rate through chemical reaction kinetics and controlling the ignition strategy of the engine are the most important contents in HCCI combustion [29]. A single fuel or fuel mixture can be used to control the ignition of different types of engines and the chemical reaction rates of the fuel in HCCI combustion process [30-32]. At present, a variety of fuels including biodiesel, n-butanol and n-heptane have been used in HCCI engines for research [33-37].

Therefore, the purpose of the study is to apply the HCCI combustion method to a marine diesel engine and reduce engine emissions of diesel. The method of reducing engine emissions in diesel surrogate fuel (77\% n-dodecane and $23 \%$ m-xylene mixture) HCCI combustion by mixing with n-butanol in a two-stroke diesel engine is first proposed in the research.

\section{Kinetic Models and Methods}

The IC engine module in the CHEMKIN-PRO software is used to simulate a lowspeed two-stroke diesel engine HCCI combustion. The selected model is the B\&W 6S70MC engine produced by MAN. This research combines the parameters of this engine model with closed internal combustion on engine simulator and applies the HCCI combustion method to a marine diesel engine to study the effects of n-butanol on diesel surrogate fuel HCCI combustion and emission characteristics. The fuel is completely homogeneously mixed with the air during the intake and compression strokes to form a lean, homogeneous mixture. When the piston is compressed to the vicinity of the TDC, the combustion of the mixed gas in the cylinder is realized by the self-ignition of the air-fuel mixture. Table 1 shows the main technical parameters of the diesel engine [38]. 
Table 1. Test engine parameters and specifications.

\begin{tabular}{cc}
\hline Item & Data \\
\hline Engine speed & $85 \mathrm{rpm}$ \\
Effective power & $13,364 \mathrm{~kW}$ \\
Mean effective pressure & $15.27 \mathrm{bar}$ \\
Stroke & $3674 \mathrm{~mm}$ \\
Number of cylinders & 6 \\
Connecting rod length & $3066 \mathrm{~mm}$ \\
Cylinder diameter & $700 \mathrm{~mm}$ \\
\hline
\end{tabular}

The diesel surrogate fuel (77\% n-dodecane and 23\% m-xylene) reaction mechanism model came from the Lawrence Livermore National Laboratory [13], which is defined as DX in this study. The n-butanol combustion reaction mechanism came from the National University of Ireland [39]. The $\mathrm{NO}_{\mathrm{x}}$ combustion reaction mechanism came from the $\mathrm{C} 0-\mathrm{C} 1$ $\mathrm{NO}_{\mathrm{x}}$ mechanism of the National University of Ireland [40]. These mechanisms were combined through ANSYS Workbench to eliminate duplicate reactions and redundant species. Then, a detailed mixed fuel combustion reaction kinetics mechanism was constructed to study the HCCI combustion and emission characteristics of two-stroke diesel engines. Table 2 shows the comparison of the properties of n-butanol, DX [41] and actual diesel [41]. The cetane number of DX is much higher than that of actual diesel, while the cetane number of n-butanol is lower. Therefore, the cetane number of mixed fuel can be reduced to close to the cetane number of actual diesel by mixing with n-butanol.

Table 2. Properties of fuels.

\begin{tabular}{cccc}
\hline Property & Diesel & DX & n-Butanol \\
\hline C/H mass ratio & 6.53 & 5.96 & 4.80 \\
Lower heating value (MJ/kg) & 42.98 & 43.33 & 35.10 \\
Oxygen content (weight \%) & 0 & 0 & 21.6 \\
Cetane number & 46 & 70 & 12 \\
\hline
\end{tabular}

The actual equivalence ratio of the low-speed two-stroke diesel engine is generally 0.45 to 0.5 . In this study, the equivalence ratio is 0.5 . Four different initial intake pressures of $0.8,1.0,1.2$, and $1.4 \mathrm{~atm}$ are selected as the pressure boundary conditions of the two-stroke diesel engine HCCI combustion. Four different initial intake temperatures of 380, 400, 420, and $440 \mathrm{~K}$ are selected as the temperature boundary conditions for DX HCCI combustion. At a certain total mole fraction, DX and n-butanol are mixed in different proportions, and the mixing ratio of $n$-butanol increases gradually. Table 3 shows the mole fraction and cetane number of mixed fuel and air. Argon is used as the filling gas and does not participate in the actual reaction.

Table 3. Species composition ratio and cetane number of DX-NB mixtures.

\begin{tabular}{cccccc}
\hline $\begin{array}{c}\text { Mole } \\
\text { Fraction of } \\
\text { DX }\end{array}$ & $\begin{array}{c}\text { Mole } \\
\text { Fraction of } \\
\text { NB }\end{array}$ & $\begin{array}{c}\text { Mole } \\
\text { Fraction of } \\
\mathbf{O}_{\mathbf{2}}\end{array}$ & $\begin{array}{c}\text { Mole } \\
\text { Fraction of } \\
\mathbf{N}_{\mathbf{2}}\end{array}$ & $\begin{array}{c}\text { Mole } \\
\text { Fraction of } \\
\mathbf{A r}\end{array}$ & $\begin{array}{c}\text { Cetane } \\
\text { Number }\end{array}$ \\
\hline 1.0 & 0 & 33.32 & 125.35 & 0 & 70.0 \\
0.9 & 0.1 & 31.19 & 117.33 & 10.15 & 64.2 \\
0.8 & 0.2 & 29.06 & 109.32 & 20.29 & 58.4 \\
0.7 & 0.3 & 26.92 & 101.27 & 30.48 & 52.6 \\
0.6 & 0.4 & 24.79 & 93.26 & 40.62 & 46.8 \\
\hline
\end{tabular}

\section{Results and Discussion}

This article first verifies the reliability of the skeleton mechanism by comparing the ignition delay with the experiment. Then, the effects of different initial conditions and 
n-butanol blending ratio on two-stroke diesel engine DX HCCI combustion are researched in the study.

\subsection{Ignition Delay Verification of DX-NB-NO ${ }_{x}$ Skeleton Mechanism}

The ignition delay data come from the simulation results of fuel in CHEMKIN closed internal combustion on engine simulator under different equivalence ratios. Figures 1-3 show the comparison of $n$-dodecane ignition delay time between the mixed fuel skeleton mechanism and the experimental value [42]. It can be seen that the study selects three different equivalence ratios $(0.5,1.0$ and 1.5) for comparison at 8 atm and 15 atm respectively. The simulation results are in good agreement with the experimental values in the hightemperature stage, and there are some differences in the low-temperature stage. This is because the experimental data of fuel ignition delay are obtained from the shock tube experiment, while the simulated ignition delay results come from diesel engine combustion. There are some differences in the working mode between two styles. Therefore, there is a certain difference between the diesel engine combustion simulation results and the shock tube experimental data. The overall trend of two modes is consistent, and the error is within a reasonable range. So, the reliability of the combustion simulation of $n$-dodecane in the newly constructed combustion reaction mechanism can be guaranteed.
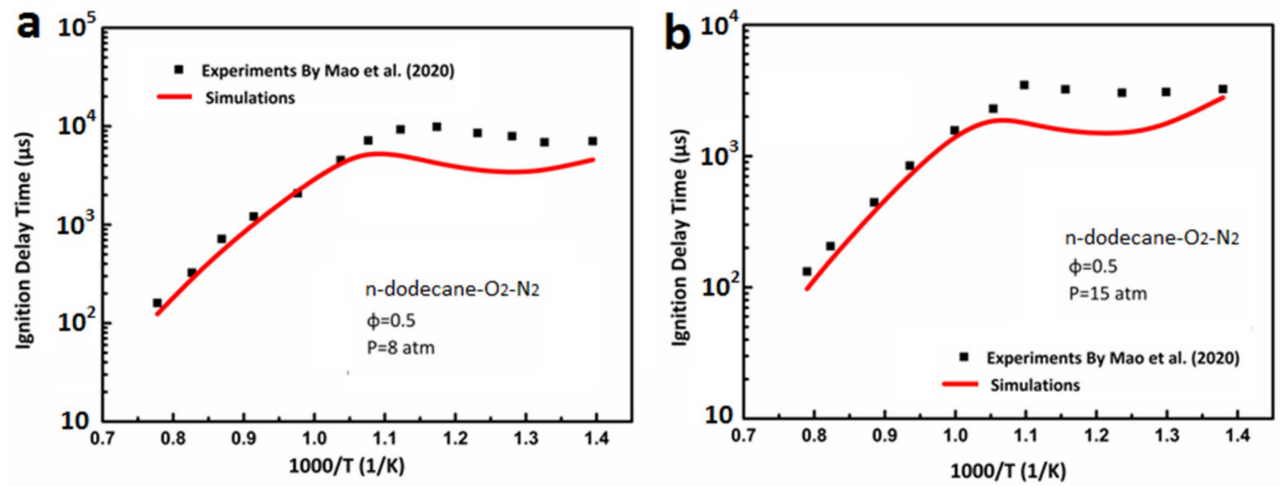

Figure 1. (a) Comparison of simulated and experimental ignition delay time of $n$-dodecane at $\Phi=0.5$, $8 \mathrm{~atm}$; (b) Comparison of simulated and experimental ignition delay time of $\mathrm{n}$-dodecane at $\Phi=0.5$, $15 \mathrm{~atm}$.
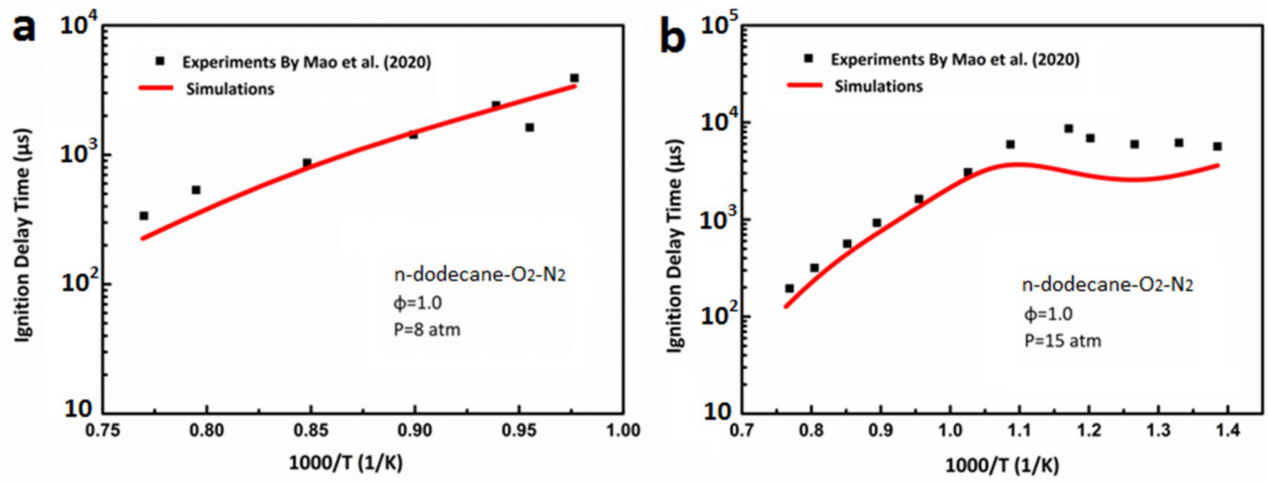

Figure 2. (a) Comparison of simulated and experimental ignition delay time of n-dodecane at $\Phi=1.0$, $8 \mathrm{~atm}$; (b) Comparison of simulated and experimental ignition delay time of n-dodecane at $\Phi=1.0$, $15 \mathrm{~atm}$. 

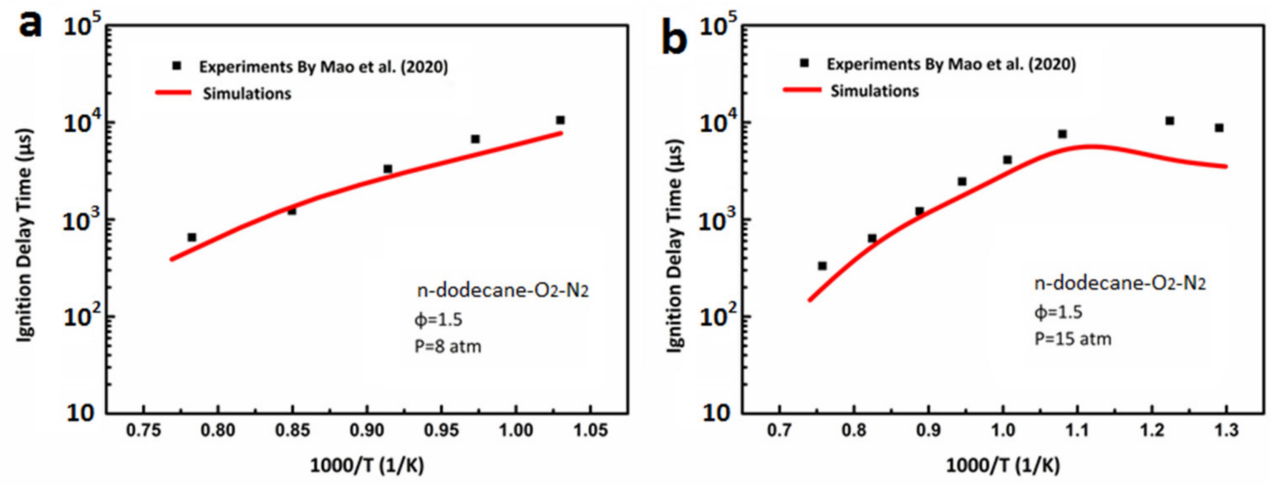

Figure 3. (a) Comparison of simulated and experimental ignition delay time of $\mathrm{n}$-dodecane at $\Phi=1.5$, $8 \mathrm{~atm}$; (b) Comparison of simulated and experimental ignition delay time of n-dodecane at $\Phi=1.5$, $15 \mathrm{~atm}$.

Figure 4 shows the comparison of $\mathrm{n}$-butanol ignition delay time between the newly constructed fuel mechanism and the experimental value [43]. It can be seen that the ignition delay times of n-butanol at three different pressures of 1.5, 3, and $42 \mathrm{~atm}$ are compared with the experimental values at the equivalent ratio of 1.0. The results show that the ignition delay time of $\mathrm{n}$-butanol in the newly constructed mechanism was consistent with the experimental value, which ensured the reliability of the combustion simulation of $\mathrm{n}$-butanol in the newly constructed combustion reaction mechanism.
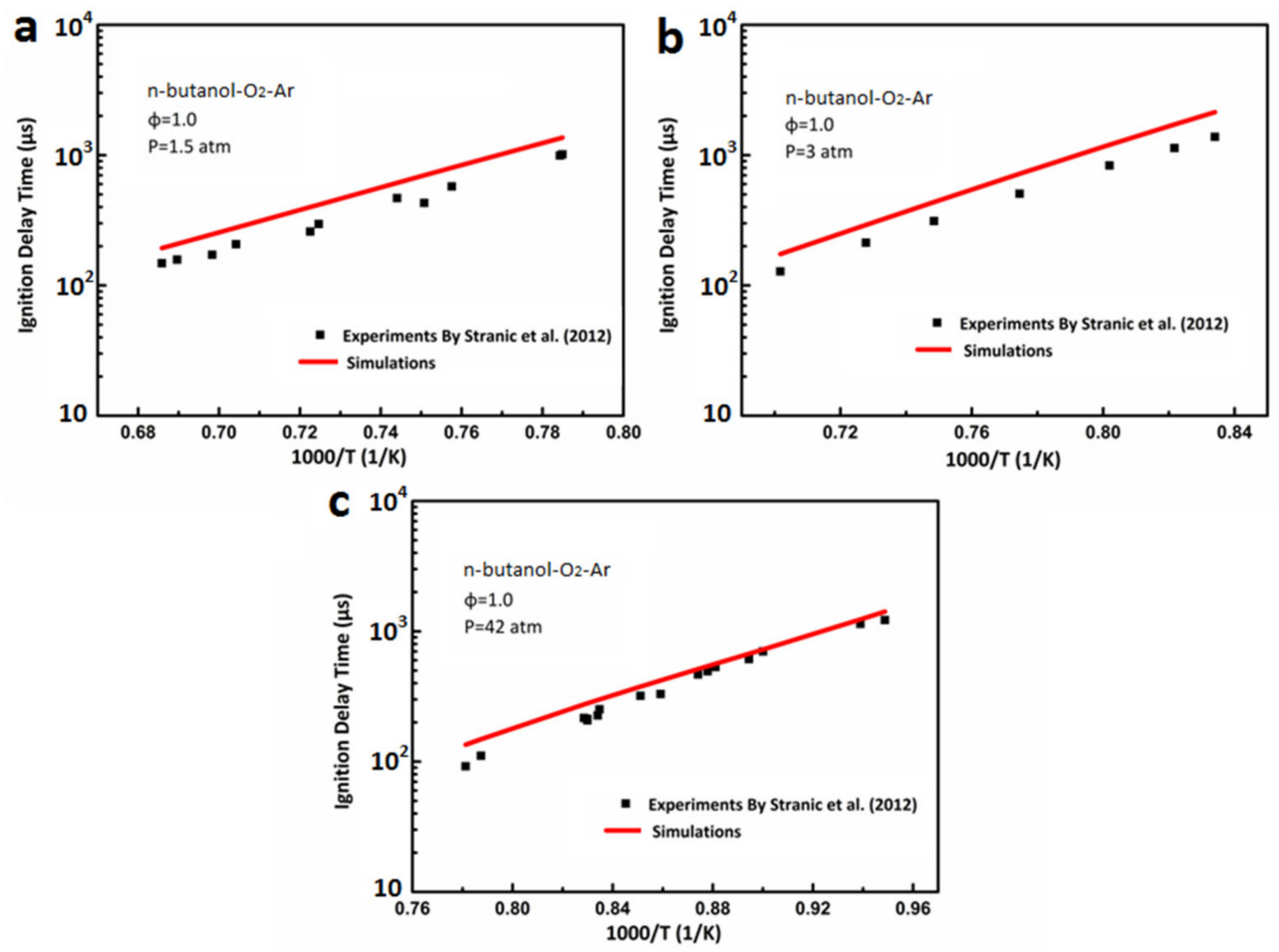

Figure 4. (a) Comparison of simulated and experimental ignition delay time of n-butanol at $\Phi=1.0$, $1.5 \mathrm{~atm}$; (b) Comparison of simulated and experimental ignition delay time of $\mathrm{n}$-butanol at $\Phi=1.0$, $3 \mathrm{~atm}$; (c) Comparison of simulated and experimental ignition delay time of n-butanol at $\Phi=1.0$, $42 \mathrm{~atm}$.

\subsection{Effect of Initial Pressure on DX HCCI Combustion and NO Emissions}

In order to keep the combustion pressure consistent with the actual two-stroke diesel engine in the cylinder, at an equivalence ratio of 0.5 and an initial temperature of $400 \mathrm{~K}$, 
four different pressures of $0.8,1.0,1.2$, and $1.4 \mathrm{~atm}$ are selected as the initial pressure of the two-stroke diesel engine HCCI combustion. Figure 5 shows the effect of different initial pressures on the in-cylinder pressure in the DX HCCI combustion. It can be seen that the peak combustion pressure increases with an increase of initial pressure. When the initial pressure is $1.4 \mathrm{~atm}$, the DX HCCI combustion pressure is consistent with the experimental pressure [38]. The actual combustion pressure in the cylinder rises to the highest point after the top dead center (TDC) compared with HCCI combustion. The reason is that $\mathrm{HCCI}$ is an ideal combustion mode, multiple ignition points are distributed in the cylinder. When the fuel reaches ignition conditions, all the fuel is combusted at the same time in the cylinder, and the pressure rises to the highest point instantly in the cylinder. The fuel combustion reaction needs some time to progress gradually in the actual diesel engine, the fuel is completely burned after the TDC, and the cylinder pressure reaches the maximum. Therefore, the study selects $1.4 \mathrm{~atm}$ as the initial combustion pressure of the two-stroke engine without affecting the engine efficiency.

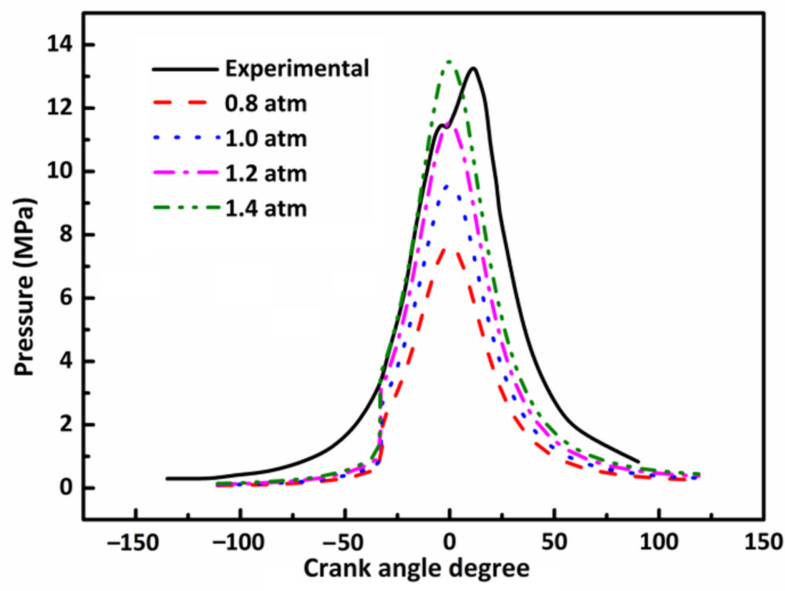

Figure 5. Comparison of different initial pressures and experimental pressure.

Figure 6 shows the effect of different initial combustion pressures on $\mathrm{NO}$ emissions. NO increases very slightly with the increase of initial intake pressure at a 0 crank angle degree. This is because the increase of pressure leads to an increase in the reaction rate of NO formation at the TDC, which increases the production of NO. It can be seen that the NO emission decreases slightly with the increase of initial pressure at a 50-119 crank angle degree. The reason is that the increase in combustion pressure accelerates the disturbance of the gas in the cylinder, speeds up the destruction of $\mathrm{NO}$, and reduces the final production of NO. Therefore, the increase of initial combustion pressure can help to reduce NO emissions.

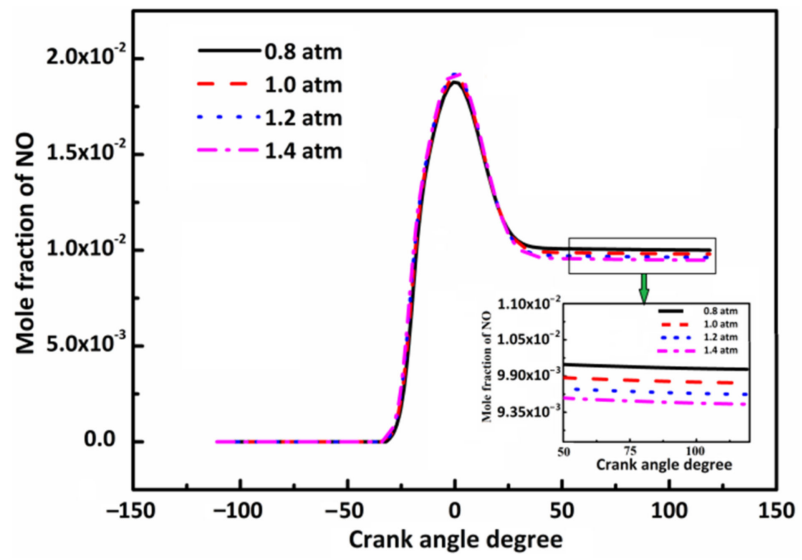

Figure 6. Effect of initial combustion pressures on NO emissions. 


\subsection{Effect of Initial Combustion Temperature on DX HCCI Combustion and NO Emissions}

At a constant initial combustion pressure of $1.4 \mathrm{~atm}$, equivalence ratio of 0.5 . The study selects $380,400,420$, and $440 \mathrm{~K}$ as the initial combustion temperatures for DX HCCI combustion. Figure 7 shows that when the initial temperatures are $400 \mathrm{~K}$ and $420 \mathrm{~K}$, the combustion peak pressures in the cylinder are close to the actual combustion pressure [38]. At the same time, the fuel ignition delay time at $420 \mathrm{~K}$ is shorter than that at $400 \mathrm{~K}$, so DX HCCI combustion can be synchronized with the actual combustion pressure curve earlier at the initial temperature of $420 \mathrm{~K}$.

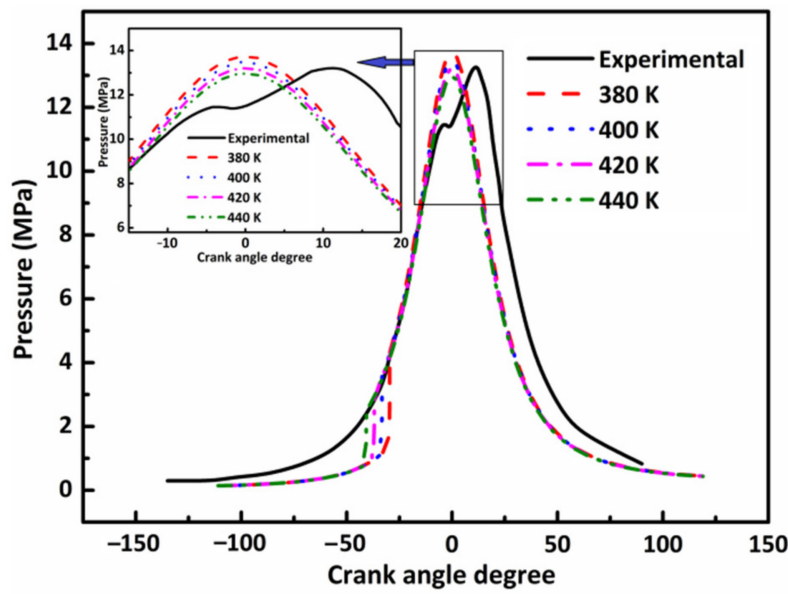

Figure 7. Effect of initial combustion temperatures on in-cylinder pressure.

Figure 8 shows the effect of different initial combustion temperatures on $\mathrm{NO}$ emissions. It can be seen that the NO emissions at the TDC increase significantly with an increase of initial temperature, which is because the maximum in-cylinder combustion temperatures rise with the increase of the initial temperature. The final emissions of $\mathrm{NO}$ at the exhaust port increase slightly at different initial temperatures.

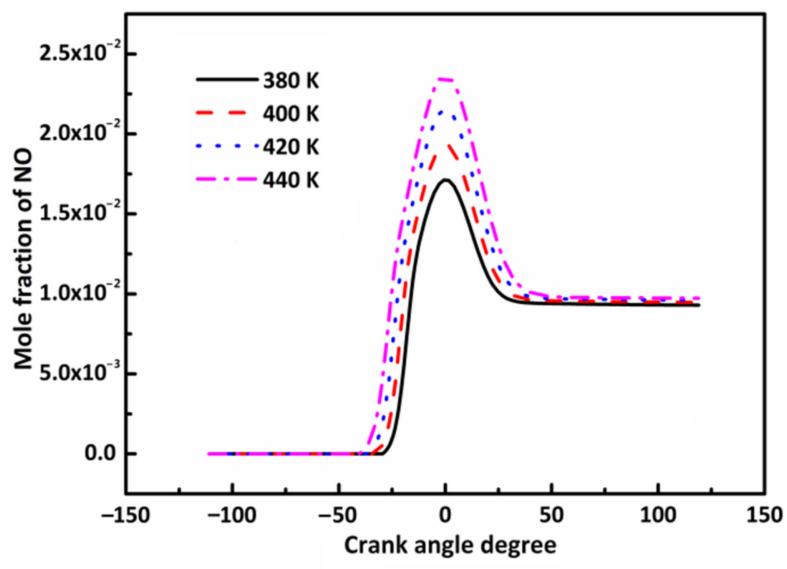

Figure 8. Effect of initial combustion temperatures on $\mathrm{NO}$ emissions.

Therefore, the DX HCCI combustion will not increase significantly at the initial combustion temperature of $420 \mathrm{~K}$. The simulated combustion pressure can maintain a good consistency with the actual diesel engine combustion pressure in the cylinder. 


\subsection{Effect of n-Butanol on DX HCCI Combustion and Emission Characteristics}

\subsubsection{Effect of $\mathrm{n}$-Butanol Blending Ratio on the Ignition Delay Time}

At a constant engine speed of $85 \mathrm{rpm}$, equivalence ratio of 0.5 , the total mole fraction of the mixed fuel is fixed. Figure 9 a shows the effect of n-butanol blending ratio on the ignition delay time of the high-temperature part. It can be seen that when the temperature is higher than $1100 \mathrm{~K}$, the ignition delay time of the mixed fuel rises with the increase of $\mathrm{n}$-butanol blending ratio. The same trend also appears in the low-temperature stage (Figure $9 \mathrm{~b}$ ). The ignition delay time increases significantly with the increase of $n$-butanol blending ratio when the temperature is lower than $830 \mathrm{~K}$. This is because the cetane number of n-butanol is lower than that of DX (Table 2). With the increase of n-butanol mixing ratio, the cetane number of the mixed fuel decreases. As a result, the ignition delay time of the mixed fuel becomes longer. The fuel and air have more time to mix fully and uniformly before the combustion starts, which can improve the fuel combustion efficiency effectively. The cetane number of DX is higher than that of diesel, and the cetane number of n-butanol is lower than that of diesel (Table 2). Therefore, adding a certain proportion of n-butanol to DX can make the cetane number of the mixed fuel closer to real diesel. It can be seen that when the blending ratio of n-butanol is $40 \%$, the cetane number of the mixed fuel is closest to real diesel (Table 3).
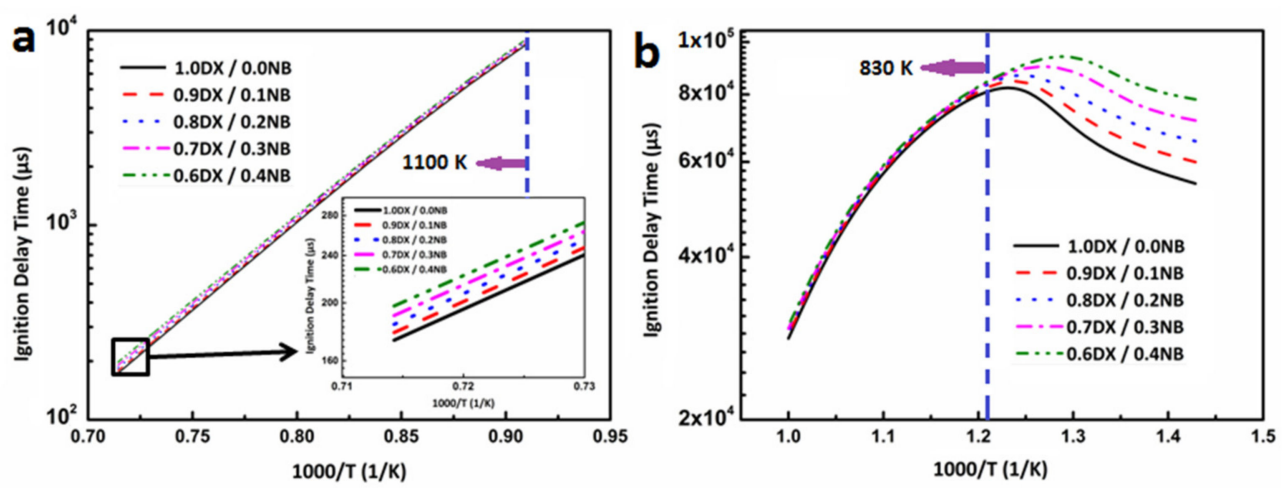

Figure 9. (a) Effect of DX and n-butanol blending ratio on high-temperature ignition delay; (b) Effect of DX and n-butanol blending ratio on low-temperature ignition delay.

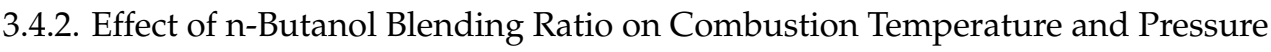

Figure 10 shows that the combustion temperature decreases with an increase of $n-$ butanol percentage at a constant equivalence ratio of 0.5 . This is because the lower heating value of n-butanol is lower than that of DX, the total heating value of fuel reduces with the increase of n-butanol percentage at the constant total mole fraction. The difference between the heating value of DX and n-butanol is not very large, it will not cause a significant decrease in the temperature of the main combustion process. However, the lower heating value will shorten the combustion process time. When the fuel is completely burned, the lower the heating value, the faster the combustion temperature decreases. The reduction of combustion temperature helps to reduce the production of thermal $\mathrm{NO}_{\mathrm{x}}$. Therefore, the combustion temperature can be adjusted in an appropriate range by regulating the mixing ratios of DX and n-butanol to decrease $\mathrm{NO}_{\mathrm{x}}$ emissions 


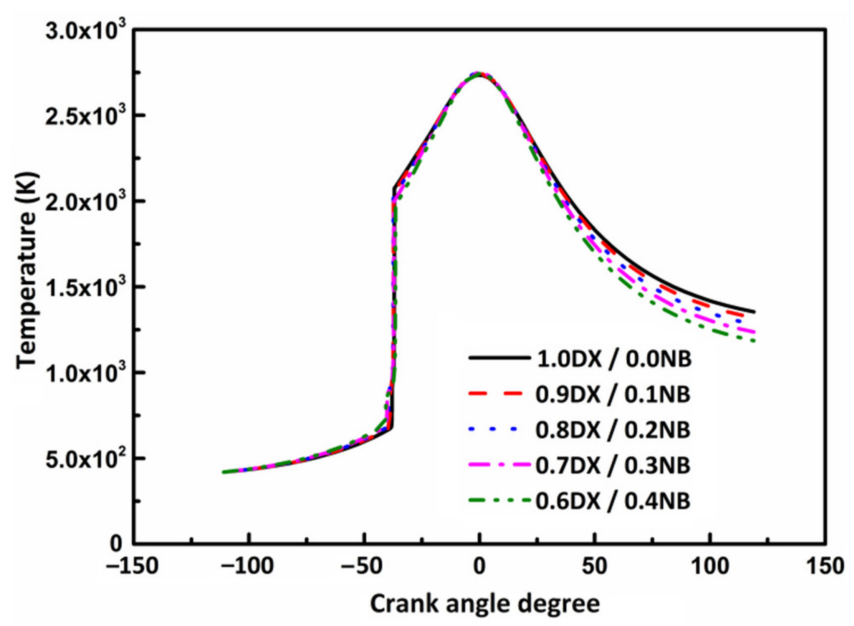

Figure 10. Effect of DX and n-butanol mixing ratio on combustion temperature in cylinder.

Figure 11 shows the effect of n-butanol mixing ratio on in-cylinder combustion pressure. It can be seen that the combustion pressure has not obvious change with the increase of n-butanol mixing ratio in a two-stroke diesel engine. Therefore, adding $\mathrm{n}$-butanol to DX HCCI combustion will not cause a major change to the engine combustion pressure, which ensures the working efficiency of the engine.

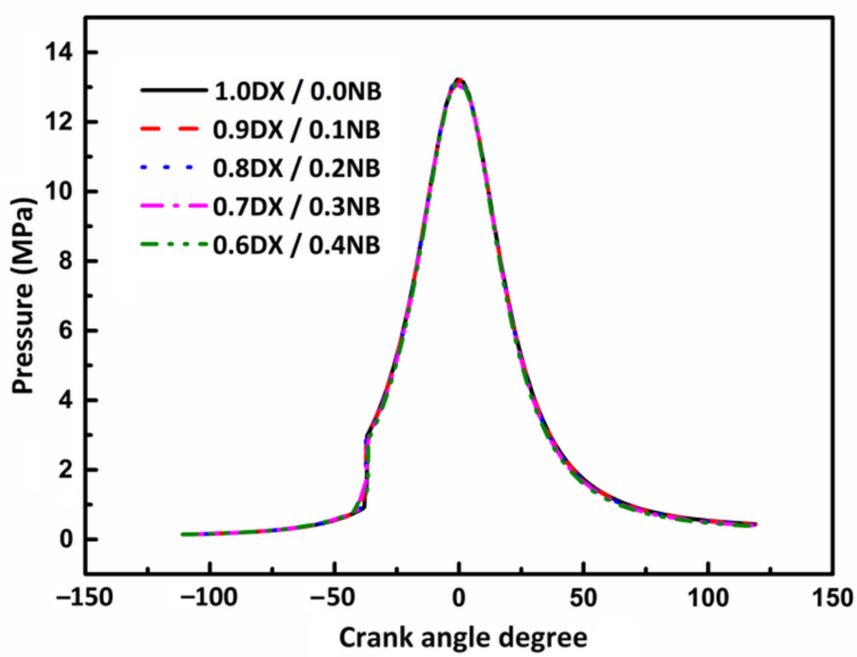

Figure 11. Effect of DX and n-butanol mixing ratio on combustion pressure in cylinder.

\subsubsection{Effect of $\mathrm{n}$-Butanol Blending Ratio on $\mathrm{NO}_{\mathrm{x}}$ Emissions}

Figure 12a shows the effect of DX and n-butanol blending ratio on NO emissions. It can be seen that $\mathrm{NO}$ emissions decrease significantly with the increase of $\mathrm{n}$-butanol mixing ratio. When the blending ratio of $n$-butanol increases from $0 \%$ to $40 \%$, the final $\mathrm{NO}$ emissions decreased by $21.9 \%$ (Figure $12 \mathrm{~b}$ ). Therefore, NO emissions can be reduced effectively by adding the $n$-butanol mixing ratio. 

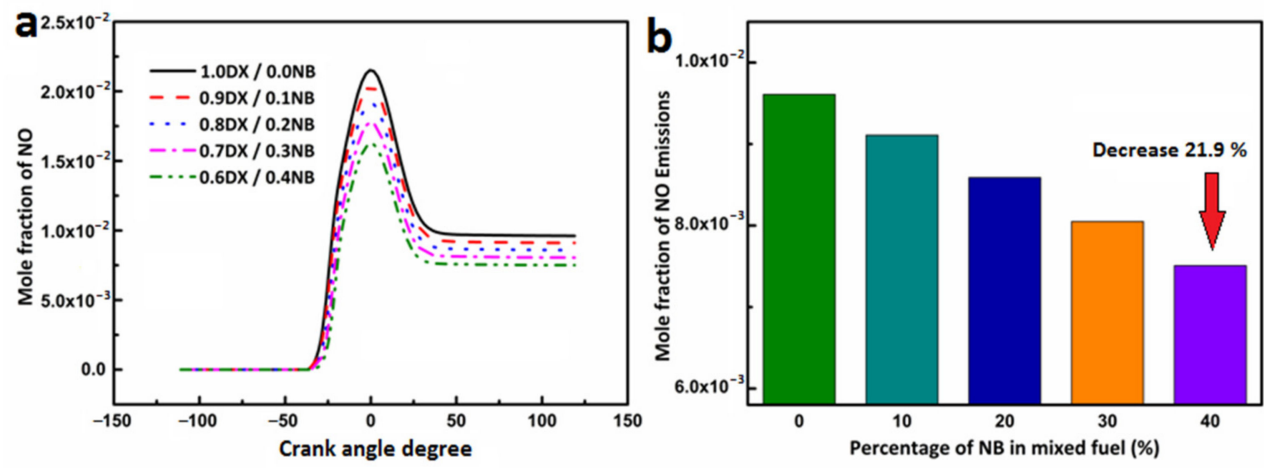

Figure 12. (a) Effect of DX and n-butanol blending ratio on $\mathrm{NO}$ emissions; (b) Effect of n-butanol percentage on final NO emissions.

The same trend also appears in $\mathrm{NO}_{2}$ emissions (Figure 13a). It can be seen that the final emission of $\mathrm{NO}_{2}$ shows a downward trend with the increase of n-butanol mixing ratio. It can be clearly seen that with the blending ratio of n-butanol increases from $0 \%$ to $40 \%$, the final $\mathrm{NO}_{2}$ emissions decrease by $7.8 \%$ from Figure $13 \mathrm{~b}$. Therefore, $\mathrm{NO}_{2}$ emissions can be reduced effectively by adding n-butanol in DX HCCI combustion.
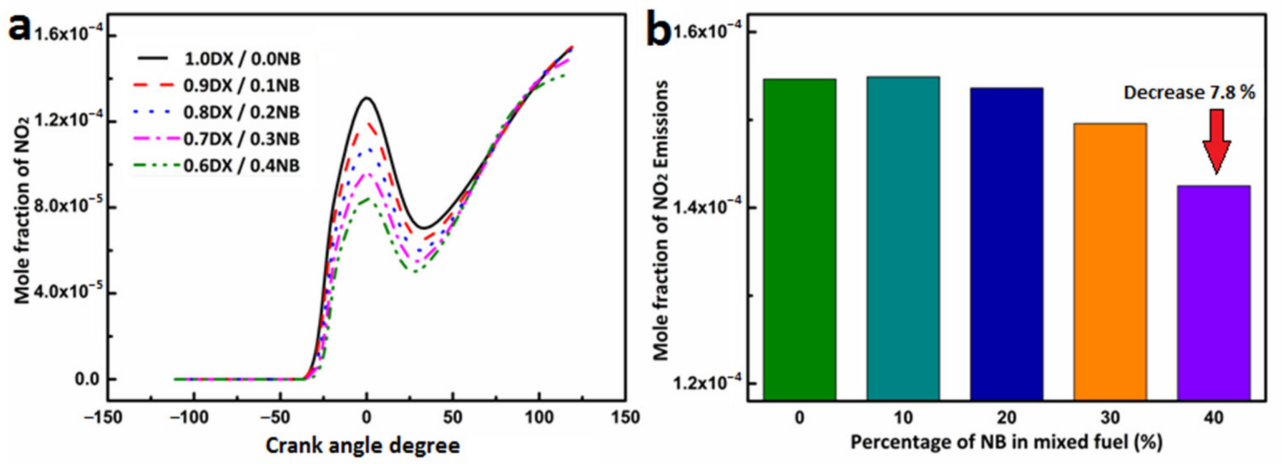

Figure 13. (a) Effect of DX and n-butanol mixing ratio blending ratio on $\mathrm{NO}_{2}$ emissions; (b) Effect of n-butanol percentage on final $\mathrm{NO}_{2}$ emissions.

$\mathrm{NO}_{\mathrm{x}}$ emissions show an obvious downward trend with the increase of n-butanol blending ratio. The main reason is that the lower heating value of DX is higher than that of $\mathrm{n}$-butanol. The total heating value of fuel decreases with the increase of n-butanol blending ratio, causing the combustion temperature in the cylinder to decrease, which leads to a decrease in $\mathrm{NO}_{x}$ emissions. At the same time, the increase of $\mathrm{n}$-butanol blending ratio leads to a lower cetane number of the mixed fuel and increases the ignition delay time. The fuel has sufficient time for uniform mixing and shortens the combustion process. Since long-time combustion is also an important factor that causes the increase of $\mathrm{NO}_{\mathrm{x}}$ emissions. Therefore, the $\mathrm{NO}_{\mathrm{x}}$ emissions can be reduced by shortening the combustion process.

\subsubsection{Effect of n-Butanol Blending Ratio on $\mathrm{NO}_{x}$ Reaction Rate}

Figure 14 shows the effect of $\mathrm{n}$-butanol blending ratio on the chemical reaction rate of NO produced at the maximum combustion temperature in the cylinder. The main reaction paths of NO generation at the in-cylinder combustion peak temperature are indicated by the following chemical equations:

$$
\begin{gathered}
\mathrm{HNO}+\mathrm{N}_{2} \leftrightarrow \mathrm{NO}+\mathrm{NNH} \\
\mathrm{NO}_{2} \leftrightarrow \mathrm{NO}+\mathrm{O}
\end{gathered}
$$




$$
\begin{gathered}
\mathrm{NO}_{2}+\mathrm{OH} \leftrightarrow \mathrm{NO}+\mathrm{HO}_{2} \\
\mathrm{~N}_{2}+\mathrm{O} \leftrightarrow \mathrm{NO}+\mathrm{N}
\end{gathered}
$$

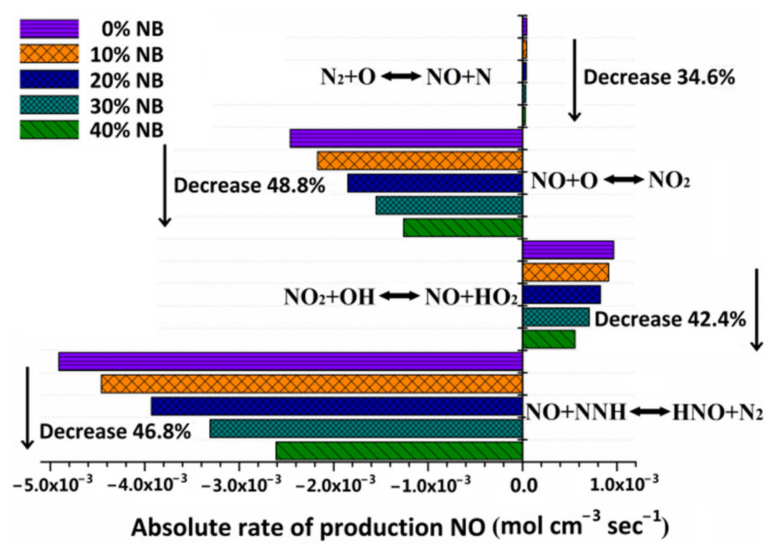

Figure 14. Effect of n-butanol mixing ratio on NO formation rate.

It can be seen that the reaction rate of NO decreases significantly with the increase of $\mathrm{n}$-butanol mixing ratio. The maximum reduction of $\mathrm{NO}$ production rate can reach about $48.8 \%$. The main reason is that the increase of $n$-butanol mixing ratio leads to a decrease in the total heating value of the mixed fuel, which reduces the in-cylinder combustion temperature. The lower combustion temperature suppresses the perturbation of the gas in the cylinder. Therefore, the production rate and emissions of NO are reduced effectively.

Figure 15 shows the effect of n-butanol blending ratio on the chemical reaction rate of $\mathrm{NO}_{2}$ produced at the maximum combustion temperature in the cylinder. The main reaction paths of $\mathrm{NO}_{2}$ generation at the in-cylinder combustion peak temperature are indicated by the following chemical equations:

$$
\begin{gathered}
\mathrm{HONO}+\mathrm{OH} \leftrightarrow \mathrm{NO}_{2}+\mathrm{H}_{2} \mathrm{O} \\
\mathrm{NO}+\mathrm{OH} \leftrightarrow \mathrm{NO}_{2}+\mathrm{H}
\end{gathered}
$$

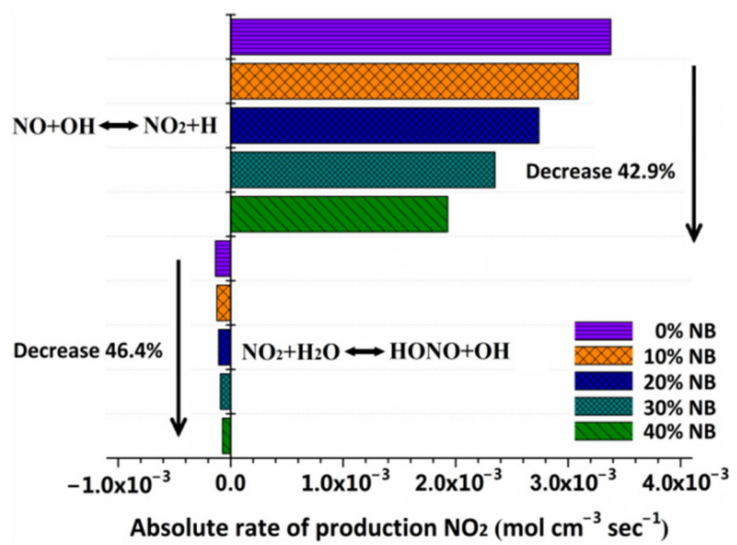

Figure 15. Effect of $\mathrm{n}$-butanol mixing ratio on $\mathrm{NO}_{2}$ formation rate.

It's the same as the decrease of NO reaction rate, the total heating value of the mixed fuel decreases with the increase of n-butanol blending ratio, which reduces the combustion temperature in the cylinder. The lower combustion temperature suppresses the perturbation of the gas in the cylinder, the combustion reaction rate of $\mathrm{NO}_{2}$ decreases, which leads 
to a reduction in $\mathrm{NO}_{2}$ emissions. The $\mathrm{NO}_{2}$ generation rate can be reduced by about $46.4 \%$ at most.

It can be seen that the combustion reaction rate and emissions of $\mathrm{NO}_{\mathrm{x}}$ reduces significantly with the increase of $\mathrm{n}$-butanol mixing ratio. When the blending ratio of $\mathrm{n}$-butanol reaches $40 \%$, the production rate of $\mathrm{NO}$ and $\mathrm{NO}_{2}$ can be reduced by more than $40 \%$. Therefore, $\mathrm{NO}_{\mathrm{x}}$ emissions can be reduced effectively by increasing $\mathrm{n}$-butanol mixing ratio in a suitable range.

\subsubsection{Effect of n-Butanol Blending Ratio on $\mathrm{CO}_{2}$ Emissions}

Figure 16 shows the effect of DX and n-butanol mixing ratio on $\mathrm{CO}_{2}$ emissions at an equivalence ratio of 0.5 . It can be seen that the $\mathrm{CO}_{2}$ emissions decrease significantly with the increase of $n$-butanol blending ratio. The reason for the decrease in $\mathrm{CO}_{2}$ production is that the $\mathrm{C} / \mathrm{H}$ ratio of $\mathrm{n}$-butanol is lower than that of $\mathrm{DX}$. The $\mathrm{C} / \mathrm{H}$ ratio of the mixed fuel decreases with the increase of n-butanol. Therefore, it can be known that $\mathrm{CO}_{2}$ emissions in two-stroke diesel engine HCCI combustion reduce significantly with an increase of n-butanol mixing ratio.

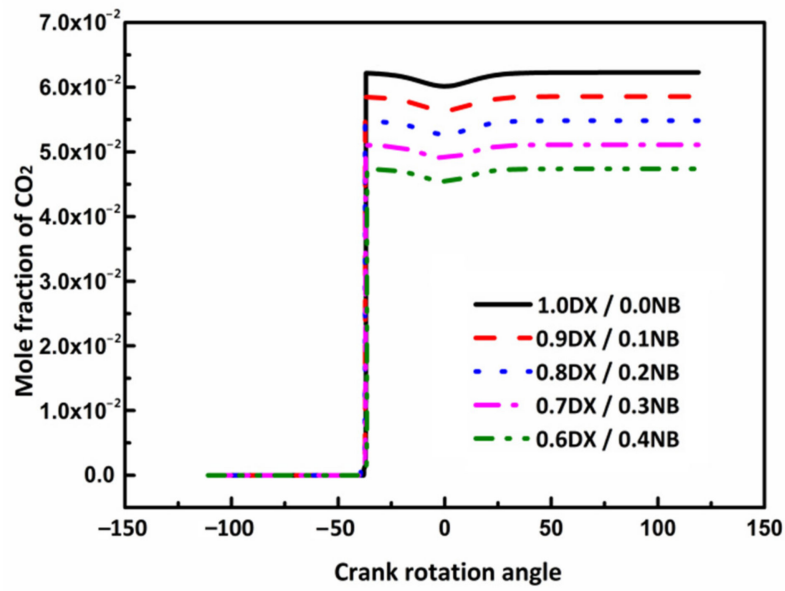

Figure 16. Effect of DX and n-butanol blending ratio on $\mathrm{CO}_{2}$ emissions.

Figure 17 shows the effect of $\mathrm{n}$-butanol blending ratio on the $\mathrm{C} / \mathrm{H}$ mass ratio and the final $\mathrm{CO}_{2}$ emissions of the mixed fuel. It can be clearly seen that the $\mathrm{C} / \mathrm{H}$ mass ratio of the mixed fuel decreases significantly with the increase of $n$-butanol mixing ratio. The decrease of the $\mathrm{C} / \mathrm{H}$ mass ratio leads to the reduction of the final $\mathrm{CO}_{2}$ emissions. The final $\mathrm{CO}_{2}$ emission decreases by about $23.9 \%$ when the blending ratio of $\mathrm{n}$-butanol reaches $40 \%$. Therefore, $\mathrm{C} / \mathrm{H}$ mass ratio and $\mathrm{CO}_{2}$ emissions of the two-stroke diesel engine HCCI combustion can be reduced effectively by increasing the n-butanol mixing ratio in a suitable range. 


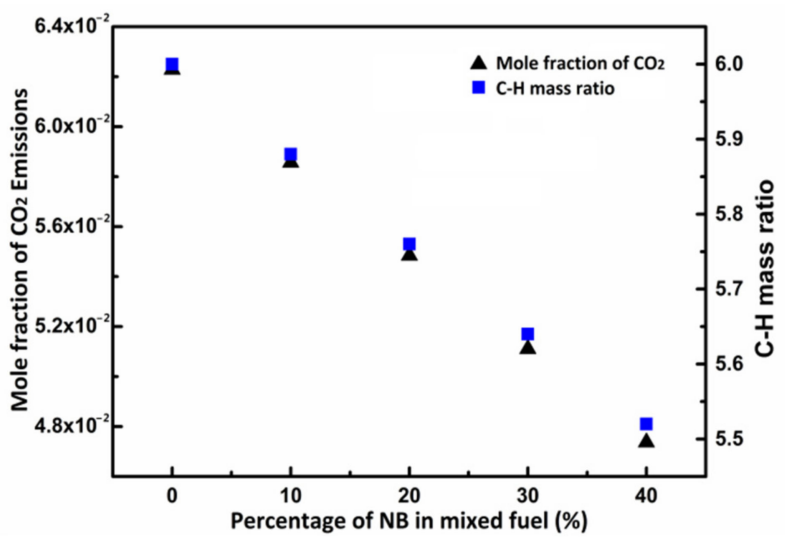

Figure 17. Effect of n-butanol percentage on $\mathrm{C}-\mathrm{H}$ mass ratio and final $\mathrm{CO}_{2}$ emissions.

\section{Conclusions}

A mixture of $n$-dodecane and m-xylene was used as an alternative fuel for diesel. The complete combustion reaction mechanism of diesel (DX), n-butanol and $\mathrm{NO}_{\mathrm{x}}$ was established for two-stroke diesel engine HCCI combustion. Through the sensitivity analysis, ignition delay time, combustion temperature, in-cylinder pressure, $\mathrm{NO}_{x}$ and $\mathrm{CO}_{2}$ emissions were obtained for different $n$-butanol mixture ratios during the diesel alternative fuel DX HCCI combustion. Through the analysis of reaction paths, the main formation path and chemical reaction rate of $\mathrm{NO}_{\mathrm{x}}$ were observed accurately. The main findings from this research are as follows:

The peak combustion pressure increased with an increase of initial intake pressure from 0.8 to $1.4 \mathrm{~atm}$ on low-speed two-stroke diesel engines HCCI combustion. The combustion pressure of the model used at $1.4 \mathrm{~atm}$ in the cylinder was consistent with the actual combustion pressure. The final NO emissions decreased slightly with the increase of initial intake pressure.

The ignition time advances with the increase of initial intake temperature from 380 to $440 \mathrm{~K}$. The combustion pressure of the model used at initial temperature of $420 \mathrm{~K}$ was consistent with the actual combustion pressure. The final NO emissions increased slightly with the increase of initial intake temperature.

Different DX and n-butanol mixing ratios were used at a constant total mole fraction. The ignition delay time increased with an increase of n-butanol ratio. The combustion temperature decreased rapidly with the increase of the n-butanol blending ratio after the TDC. The reaction rate and emissions of $\mathrm{NO}_{\mathrm{x}}$ reduced significantly with the increase of n-butanol mixing ratio. When the blending ratio of n-butanol reaches $40 \%$, the production rate of $\mathrm{NO}$ and $\mathrm{NO}_{2}$ could be reduced by more than $40 \%$. The $\mathrm{NO}_{\mathrm{x}}$ reaction rates decreased rapidly with the increase of $n$-butanol mixing ratio at the TDC. At the same time, $\mathrm{C} / \mathrm{H}$ mass ratio and the $\mathrm{CO}_{2}$ emissions decreased significantly with the increase of $\mathrm{n}$-butanol percentage. Therefore, the combustion and emission of DX HCCI combustion can be improved by increasing the n-butanol mixing ratio at the same engine load.

Author Contributions: Writing—original draft preparation, S.W.; project administration, J.Z.; writingreview and editing, L.Y. All authors have read and agreed to the published version of the manuscript.

Funding: This work was supported by Research on Intelligent Ship Testing and Verification ([2018]473). The Major Research plan of the National Natural Science Foundation of China (Grant No. 91441132).

Institutional Review Board Statement: Not applicable.

Informed Consent Statement: Not applicable.

Data Availability Statement: The data presented in this study are available on request from the first author. 


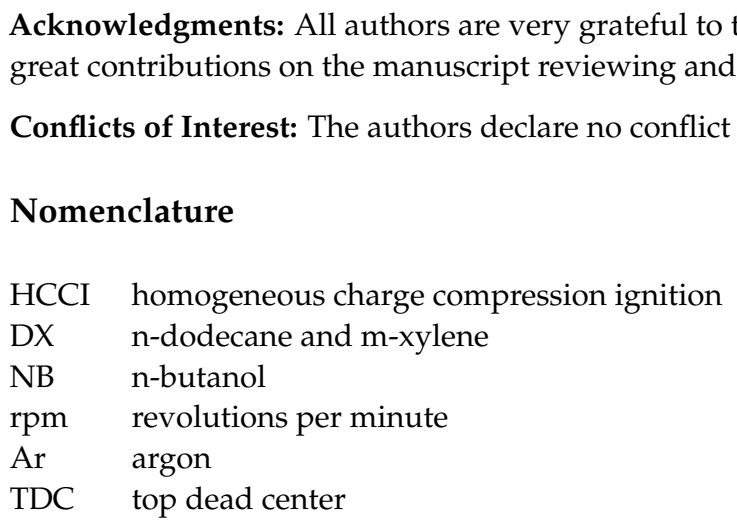

\section{References}

1. Demirbas, A. Importance of biodiesel as transportation fuel. Energy Policy 2007, 35, 4661-4670. [CrossRef]

2. Pienkos, P.T.; Darzins, A. The promise and challenges of microalgal-derived biofuels. Biofuels Bioprod. Biorefining 2009, 3, 431-440. [CrossRef]

3. Blasio, G.D.; Ianniello, R.; Beatrice, C. Hydrotreated Vegetable Oil as Enabler for High-Efficient and Ultra-Low Emission Vehicles in the View of 2030 Targets. Fuel 2022, 310, 122206. [CrossRef]

4. Cho, C.P.; Pyo, Y.D.; Jang, J.Y.; Kim, G.C.; Shin, Y.J. $\mathrm{NO}_{x}$ Reduction and $\mathrm{N}_{2} \mathrm{O}$ Emissions in A Diesel Engine Exhaust Using Fe-Zeolite and Vanadium based SCR Catalysts. Appl. Therm. Eng. 2017, 110, 18-24. [CrossRef]

5. Geng, P.; Tan, Q.; Zhang, C.; Wei, L.; He, X.; Cao, E.; Jiang, K. Experimental investigation on $\mathrm{NO}_{\mathrm{x}}$ and green house gas emissions from a marine auxiliary diesel engine using ultralow sulfur light fuel. Sci. Total Environ. 2016, 572, 467-475. [CrossRef] [PubMed]

6. Jeon, J.; Lee, J.T.; Park, S. Nitrogen Compounds $\left(\mathrm{NO}, \mathrm{NO}_{2}, \mathrm{~N}_{2} \mathrm{O}\right.$, and $\left.\mathrm{NH}_{3}\right)$ in $\mathrm{NO}_{x}$ Emissions from Commercial EURO VI Type Heavy-Duty Diesel Engines with a Urea-Selective Catalytic Reduction System. Energy Fuels 2016, 30, 6828-6834. [CrossRef]

7. European Parliament of 4 February 2009 on 2050: The Future Begins Today-Recommendations for the EU's Future Integrated Policy on Climate Change. Available online: https:/ /www.europarl.europa.eu/doceo/document/TA-6-2009-0042_EN.html (accessed on 10 January 2022).

8. Kong, S.-C.; Sun, Y.; Rietz, R.D. Modeling Diesel Spray Flame Liftoff, Sooting Tendency, and $\mathrm{NO}_{\mathrm{x}}$ Emissions Using Detailed Chemistry with Phenomenological Soot Model. J. Eng. Gas Turbines Power 2005, 129, 245-251. [CrossRef]

9. Senecal, P.K.; Richards, K.J.; Pomraning, E.; Yang, T.; Dai, M.Z.; McDavid, R.M.; Patterson, M.A.; Hou, S.; Shethaji, T. A New Parallel Cut-Cell Cartesian CFD Code for Rapid Grid Generation Applied to In-Cylinder Diesel Engine Simulations. In Proceedings of the SAE World Congress \& Exhibition, Detroit, MI, USA, 16-19 April 2007.

10. Som, S.; Aggarwal, S.K. Effects of Primary Breakup Modeling on Spray and Combustion Characteristics of Compression Ignition Engines. Combust. Flame 2010, 157, 1179-1193. [CrossRef]

11. Pitz, W.J.; Cernansky, N.P.; Dryer, F.L.; Egolfopoulos, F.N.; Farrell, J.T.; Friend, D.G.; Pitsch, H. Development of an Experimental Database and Kinetic Models for Surrogate Diesel Fuels. In Proceedings of the SAE World Congress \& Exhibition, Detroit, MI, USA, 16-19 April 2007.

12. Luo, Z.; Som, S.K.; Sarathy, S.M.; Plomer, M.; Pitz, W.J.; Longman, D.E.; Lu, T. Development and validation of an n-dodecane skeletal mechanism for spray combustion applications. Combust. Theory Model. 2014, 18, 187-203. [CrossRef]

13. Pei, Y.; Mehl, M.; Liu, W.; Lu, T.; Pitz, W.J.; Som, S. A Multi-Component Blend as A Diesel Fuel Surrogate for Compression Ignition Engine Applications. In Proceedings of the ASME 2014 Internal Combustion Engine Division Fall Technical Conference, ICEF2014-5625, Columbus, IN, USA, 19 October 2014.

14. Bowman, C.T.; Golden, D.M.; Hanson, R.K.; Pitsch, H.; Wang, L. Optimization of Synthetic Oxygenated Fuels for Diesel Engines; GCEP Technical Report; Global Climate and Energy Project (GCEP) at Stanford University: Stanford, CA, USA, 2006.

15. Ren, Y.; Huang, Z.; Miao, H.; Di, Y.; Jiang, D.; Zeng, K.; Liu, B.; Wang, X. Combustion and emissions of a DI diesel engine fuelled with diesel-oxygenate blends. Fuel 2008, 87, 2691-2697. [CrossRef]

16. Cheng, A.S.; Dibble, R.W.; Buchholz, B.A. The Effect of Oxygenates on Diesel Engine Particulate Matter. SAE Pap. $2002,1,1705$.

17. Flower, W.L. An investigation of Soot Formation in Axisymmetric Turbulent Diffusion Flames at Elevated Pressure. Symp. Combust. 1989, 22, 425-435. [CrossRef]

18. Zannis, T.; Hountalas, D.T.; Kouremenos, D.A. Experimental Investigation to Specify the Effect of Oxygenated Addition Content and Type on DI Diesel Engine Performance and Emissions. SAE Trans. 2004, 113, 166-179.

19. Yeh, L.I.; Rickeard, D.J.; Duff, J.L.C.; Bateman, J.R.; Schlosberg, R.H.; Caers, R.F. Oxygenates: An Evaluation of their Effects on Diesel Emissions. SAE Trans. 2001, 110, 1482-1498.

20. Yao, M.; Wang, H.; Zheng, Z.; Yue, Y. Experimental study of n-butanol additive and multi-injection on HD diesel engine performance and emissions. Fuel 2010, 89, 2191-2201. [CrossRef] 
21. Rakopoulos, C.D.; Dimaratos, A.M.; Giakoumis, E.G. Study of Turbocharged Diesel Engine Operation, Pollutant Emissions and Combustion Noise Radiation During Starting with Bio-diesel or N-butanol Diesel Fuel Blends. Appl. Energy 2011, 88, 3905-3916. [CrossRef]

22. Siwale, L.; Kristóf, L.; Adam, T.; Bereczky, A.; Mbarawa, M.; Penninger, A.; Kolesnikov, A. Combustion and Emission Characteristics of n-Butanol/Diesel Fuel Blend in A Turbo-Charged Compression Ignition Engine. Fuel 2013, 107, 409-418. [CrossRef]

23. Chen, G.; Shen, Y.; Zhang, Q.; Yao, M.; Zheng, Z.; Liu, H. Experimental study on combustion and emission characteristics of a diesel engine fueled with 2,5-dimethylfuran-diesel, n-butanol-diesel and gasoline-diesel blends. Energy 2013, 54, 333-342. [CrossRef]

24. Jin, C.; Yao, M.; Liu, H.; Lee, C.-F.F.; Ji, J. Progress in the production and application of n-butanol as a biofuel. Renew. Sustain. Energy Rev. 2011, 15, 4080-4106. [CrossRef]

25. Doğan, O. The Influence of n-Butanol/Diesel Fuel Blends Utilization on A Small Diesel Engine Performance and Emissions. Fuel 2011, 90, 2467-2472. [CrossRef]

26. Kumar, P.; Rehman, A. Bio-diesel in homogeneous charge compression ignition (HCCI) combustion. Renew Sustain. Energy Rev. 2016, 56, 536-550. [CrossRef]

27. Ma, J.; Lü, X.; Ji, L.; Huang, Z. An experimental study of HCCI-DI combustion and emissions in a diesel engine with dual fuel. Int. J. Therm. Sci. 2008, 47, 1235-1242. [CrossRef]

28. Dempsey, A.B.; Curran, S.J.; Wagner, R.M. A Perspective on the Range of Gasoline Compression Ignition Combustion Strategies for High Engine Efficiency and Low $\mathrm{NO}_{\mathrm{x}}$ and Soot Emissions: Effects of In-Cylinder Fuel Stratification. Int. J. Engine. Res. 2016, 17, 897-917. [CrossRef]

29. Yao, M.; Zheng, Z.; Liu, H. Progress and recent trends in homogeneous charge compression ignition (HCCI) engines. Prog. Energy Combust. Sci. 2009, 35, 398-437. [CrossRef]

30. Lu, X.C.; Han, D.; Huang, Z. Fuel Design and Management for the Control of Advanced Compression-ignition Combustion Modes. Prog. Energ. Combust. 2011, 37, 741-783. [CrossRef]

31. Olsson, J.-O.; Tunestål, P.; Johansson, B. Closed-Loop Control of an HCCI Engine. SAE Trans. 2001, 110, 1076-1185. [CrossRef]

32. Wang, S.Y.; Yao, L. Effect of Engine Speeds and Dimethyl Ether on Methyl Decanoate HCCI Combustion and Emission Characteristics Based on Low-Speed Two-Stroke Diesel Engine. Pol. Marit. Res. 2020, 27, 85-95. [CrossRef]

33. Jothi, N.M.; Nagarajan, G.; Renganarayanan, S. Experimental studies on homogeneous charge CI engine fueled with LPG using DEE as an ignition enhancer. Renew. Energy 2007, 32, 1581-1593. [CrossRef]

34. Szybist, J.P.; McFarlane, J.; Bunting, B.G. Comparison of Simulated and Experimental Combustion of Biodiesel Blends in a Single Cylinder Diesel HCCI Engine. SAE Trans. 2007, 116, 1250-1260.

35. He, B.-Q.; Yuan, J.; Liu, M.-B.; Zhao, H. Combustion and emission characteristics of a n-butanol HCCI engine. Fuel 2014, 115, 758-764. [CrossRef]

36. Maurya, R.K.; Agarwal, A.K. Combustion and Emission Characterization of n-Butanol Fueled HCCI Engine. J. Energy Resour. Technol. 2014, 137, 011101. [CrossRef]

37. Zheng, M.; Han, X.; Asad, U.; Wang, J. Investigation of butanol-fuelled HCCI combustion on a high efficiency diesel engine. Energy Convers. Manag. 2015, 98, 215-224. [CrossRef]

38. Radica, G.; Antonić, R.; Račić, N. Engine Working Cycle Analysis for Diagnostic and Optimisation Purposes. Brodogradnja 2009, 60, 378-387.

39. Black, G.; Curran, H.; Pichon, S.; Simmie, J.; Zhukov, V. Bio-butanol: Combustion properties and detailed chemical kinetic model. Combust. Flame 2010, 157, 363-373. [CrossRef]

40. Zhang, Y.; Mathieu, O.; Petersen, E.L.; Bourque, G.; Curran, H.J. Assessing the Predictions of A NOx Kinetic Mechanism on Recent Hydrogen and Syngas Experimental Data. Combust. Flame 2017, 182, 122-141. [CrossRef]

41. Kook, S.; Pickett, L.M. Liquid length and vapor penetration of conventional, Fischer-Tropsch, coal-derived, and surrogate fuel sprays at high-temperature and high-pressure ambient conditions. Fuel 2012, 93, 539-548. [CrossRef]

42. Mao, Y.; Raza, M.; Wu, Z.; Zhu, J.; Yu, L.; Wang, S.; Zhu, L.; Lu, X. An experimental study of n-dodecane and the development of an improved kinetic model. Combust. Flame 2020, 212, 388-402. [CrossRef]

43. Stranic, I.; Chase, D.P.; Harmon, J.T.; Yang, S.; Davidson, D.F.; Hanson, R.K. Shock Tube Measurements of Ignition Delay Times for the Butanol Isomers. Combust. Flame 2012, 159, 516-527. [CrossRef] 